\title{
The nutritive value of hulled and hulless barley for growing pigs. 2. Determination of in vivo and in vitro energy and in vivo ileal amino acid digestibility ${ }^{*}$
}

\author{
G. Huang ${ }^{1}$, W.C. Sauer ${ }^{1,3}$, J. He ${ }^{1}$ and M. Ramírez ${ }^{2}$ \\ ${ }^{1}$ Department of Agricultural, Food and Nutritional Science, \\ University of Alberta \\ Edmonton, Alberta, Canada T6G 2P5 \\ ${ }_{2}^{2}$ Instituto de Ciencias Agrícolas, Universidad Autónoma de Baja California \\ Mexicali, Baja California, México
}

(Received 5 March 2003; revised version 18 June 2003; accepted 28 October 2003)

\begin{abstract}
An experiment was conducted to determine the apparent ileal amino acid digestibilities in hulled and hulless barley, in addition to energy digestibility which was also determined with the in vitro method. Seven barrows, fitted with a simple T-cannula at the distal ileum, were fed seven diets $\left(180 \mathrm{~g} \mathrm{CP} \mathrm{kg}^{-1}\right)$ according to a $7 \times 7$ Latin square design. The basal diet consisted of maize starch and soyabean meal (SBM). The other diets (diets A to F) contained both SBM and barley. Diet A: hulled barley, c.v. Harrington I. Diet B: hulled barley, c.v. Harrington II. Diet C: hulless barley, c.v. CDC Buck I. Diet D: hulless barley, c.v. CDC Buck II. Denotations I and II are given to indicate two different origins of Harrington and CDC Buck. Diet E: mixture of c.v. Harrington I and c.v. CDC Buck I (50:50 wt/wt). Diet F: mixture of c.v. Harrington II and c.v. CDC Buck II (50:50 wt/wt). The mixtures were created to establish linear regression equations between the in vivo and in vitro energy digestibility values. Chromic oxide was used as the digestibility marker. The barrows were fed twice daily, at 08.00 and $20.00 \mathrm{~h}$. Each experimental period comprised 10 days. Faeces were collected from 08.00 on d 6 to 08.00 on d 8 . Ileal digesta were collected from 08.00 on d 8 until 08.00 on d 10. The initial and final average body weights of the barrows were 35 and $90 \mathrm{~kg}$, respectively. The amino acid and energy digestibility values were determined with the difference method. The apparent ileal
\end{abstract}

\footnotetext{
* Supported by the Alberta Barley Commission and the Alberta Agricultural Research Institute

${ }^{3}$ Corresponding author: e-mail: willem.sauer@ualberta.ca
} 
amino acid digestibility values were lower $(\mathrm{P}<0.05)$ in hulless than in hulled barley. The digestibilities of lysine and threonine (first- and second-limiting amino acid in barley) ranged from 58.2 to $59.4 \%$ and from 53.7 to $55.6 \%$, respectively, in hulless barley and from 62.6 to $69.7 \%$ and from 57.4 to $59.6 \%$, respectively, in hulled barley. The energy digestibility values ranged from 86.4 to $87.6 \%$ in hulless barley and from 79.9 to $81.1 \%$ in hulled barley. There was a close correlation $\left(r^{2}=0.88\right)$ between the in vivo and in vitro energy digestibility values.

KEY WORDS: pigs, digestibility, amino acids, energy, barley

\section{INTRODUCTION}

Barley is one of the major cereal grains produced in Canada. Advances in barley breeding have led to the development of hulless barley varieties. Hulless barley has a higher digestible energy content than hulled barley (e.g., Huang et al., 2003), which will likely result in increased usage in diets for pigs, especially for young pigs. In addition to digestible energy, hulless barley usually has a higher crude protein (CP) and amino acid (AA) content than hulled barley (Jaikaran et al., 1998).

There is a scarcity of information on the digestible AA content in hulless compared to hulled barley, which should be determined with the ileal analysis method (e.g., Sauer and Ozimek, 1986). Furthermore, the AA digestibility values in barley should be determined with the difference or regression rather than with the direct method (e.g., Sauer et al., 2000). As was discussed by Sauer et al. (2000), the direct method underestimates the AA digestibility values in feedstuffs with a relative low CP content.

Furthermore, the feed industry but also plant breeders would benefit greatly from an in vitro method that is rapid and inexpensive and that can accurately predict the in vivo digestible energy content in different samples of barley, including hulless barley. Recently, Huang et al. (2003) reported a close correlation between the in vivo and in vitro method for the determination of energy digestibility values in barley, albeit with a small number of samples. The in vitro method was based on procedures described by Boisen (1991).

The first objective of this experiment was to determine the apparent ileal AA digestibility values in hulless compared to hulled barley using the difference method. The second objective was to determine the energy digestibility values of the hulled and hulless barleys used in this study. In addition, the in vitro energy digestibility values determined in this study were used to expand the database in barley presented by Huang et al. (2003) for the prediction of in vivo energy digestibility values. 


\section{MATERIAL AND METHODS}

\section{Animals and diets}

Eight barrows (Camborough $\times$ Canabrid), average initial body weight $35 \mathrm{~kg}$, were obtained from the Swine Research Unit of the University of Alberta and housed individually in stainless steel metabolism crates in a temperature-controlled $\left(20\right.$ to $\left.22^{\circ} \mathrm{C}\right)$ barn. After a 10-d adaptation period to the metabolism crates, the pigs were fitted with a simple T-cannula at the distal ileum following procedures adapted from Sauer et al. (1983). The cannulas were modified according to De Lange et al. (1989). A detailed description of pre- and postoperative care was previously provided by Li et al. (1994). During the 10-d adaptation period to the crates and 14-d recuperation period from surgery, the barrows were fed a $160 \mathrm{~g}$ $\mathrm{CP} \mathrm{kg}^{-1}$ grower diet (Sauer et al., 1983). Water was freely available from a lowpressure drinking nipple. At the end of the experiment, the barrows, average body weight $90 \mathrm{~kg}$, were sacrificed and dissected to determine whether cannulation had caused adhesions or other intestinal abnormalities.

Based on feed intake and body weight, seven barrows were selected and fed seven experimental diets according to a $7 \times 7$ Latin square design. The pigs were fed twice daily, equal amounts at 08.00 and $20.00 \mathrm{~h}$. During the first experimental period, the daily dietary allowance was provided at a rate of $5 \%(\mathrm{wt} / \mathrm{wt})$ of the average body weight which was determined at the start of the first experimental period. Thereafter, the daily dietary allowance was increased by $100 \mathrm{~g}$ at each successive experimental period.

The seven experimental diets were formulated to contain $180 \mathrm{~g} \mathrm{CP} \mathrm{kg}^{-1}$ (Table 1). The basal diet consisted of maize starch and soyabean meal (SBM) (diet SBM). Soyabean meal provided the sole source of protein in this diet. The other diets (diets A to F), the assay diets, contained both SBM and barley. Diet A contained hulled barley, c.v. Harrington I. Diet B: hulled barley, c.v. Harrington II. Diet C: hulless barley, c.v. CDC Buck I. Diet D: hulless barley, c.v. CDC Buck II. Denotations I and II are given to indicate two different origins of Harrington and CDC Buck. Diet E: mixture of c.v. Harrington I and c.v. CDC Buck I (50:50 wt/wt). Diet F: mixture of c.v. Harrington II and c.v. CDC Buck II $(50: 50 \mathrm{wt} / \mathrm{wt})$. The aforementioned barleys are grown commercially. The mixtures were created in order to establish regression equations between in vivo and in vitro DM and energy digestibility values. The barleys used in this study were different from the barleys used previously by Huang et al. (2003). Canola oil was included in the diets at a level of $30 \mathrm{~g} \mathrm{~kg}^{-1}$ to reduce the dustiness of the diets. Vitamins and minerals were supplemented to meet or exceed the NRC (1998) standards. Chromic oxide $\left(25 \mathrm{~g} \mathrm{~kg}^{-1}\right)$ was included in the diets as the digestibility marker. Barley was finely ground through a $2-\mathrm{mm}$ mesh screen prior to incorporation into the diets. 
TABLE 1

Formulation of the experimental diets, $\mathrm{g} \mathrm{kg}^{-1}$ as-fed basis

\begin{tabular}{|c|c|c|c|c|c|c|c|}
\hline \multirow{2}{*}{ Ingredients } & \multicolumn{7}{|c|}{ Diets } \\
\hline & SBM & A & B & $\mathrm{C}$ & $\mathrm{D}$ & $\mathrm{E}$ & $\mathrm{F}$ \\
\hline Hulled barley (c.v Harrington I) & - & 713.0 & - & - & - & 371.6 & - \\
\hline Hulled barley (c.v Harrington II) & - & - & 740.2 & - & - & - & 377.0 \\
\hline Hulless barley (c.v CDC Buck I) & - & - & - & 774.9 & - & 371.6 & - \\
\hline Hulless barley (c.v CDC Buck II) & - & - & - & - & 768.0 & - & 377.0 \\
\hline Soyabean meal & 393.9 & 233.0 & 206.0 & 171.8 & 178.8 & 203.6 & 192.6 \\
\hline Maize starch & 420.1 & - & - & - & - & - & - \\
\hline Dextrose & 100.0 & - & - & - & - & - & - \\
\hline Cellulose $^{1}$ & 30.0 & - & - & - & - & - & - \\
\hline Canola oil & 30.0 & 30.0 & 30.0 & 30.0 & 30.0 & 30.0 & 30.0 \\
\hline Biophos ${ }^{2}$ & 13.8 & 5.1 & 5.8 & 2.4 & 2.3 & 3.7 & 3.9 \\
\hline Calcium carbonate & 4.1 & 10.1 & 9.9 & 12.8 & 12.8 & 11.4 & 11.4 \\
\hline Iodized salt ${ }^{3}$ & 3.0 & 3.0 & 3.0 & 3.0 & 3.0 & 3.0 & 3.0 \\
\hline Choline chloride $^{4}$ & 0.1 & 0.11 & 0.1 & 0.1 & 0.1 & 0.1 & 0.1 \\
\hline Mineral-vitamin premix ${ }^{5}$ & 2.0 & 2.0 & 2.0 & 2.0 & 2.0 & 2.0 & 2.0 \\
\hline Chromic oxide & 3.0 & 3.0 & 3.0 & 3.0 & 3.0 & 3.0 & 3.0 \\
\hline
\end{tabular}

${ }^{1}$ Solkafloc; supplied by James River Corp., Berlin, NH

${ }^{2}$ contained $180 \mathrm{~g} \mathrm{~kg}^{-1} \mathrm{P}$ and $240 \mathrm{~g} \mathrm{~kg}^{-1} \mathrm{Ca}$; supplied by Continental Lime Ltd., Exshaw, $\mathrm{AB}$

${ }^{3}$ provided the following ( $\mathrm{kg}^{-1}$ diet): $\mathrm{NaCI}, 2.9 \mathrm{~g}$; ZnO, $12.0 \mathrm{mg}$; $\mathrm{FeCO}_{3}, 4.8 \mathrm{mg}$; $\mathrm{MnO}, 3.6 \mathrm{mg}$; $\mathrm{CuO}, 1.0 \mathrm{mg} ; \mathrm{Ca}\left(\mathrm{IO}_{3}\right)_{2}, 0.2 \mathrm{mg}$; $\mathrm{CaO}, 0.1 \mathrm{mg}$. Supplied by Windsor Salt Co., Toronto, ON

${ }^{4}$ contained $600 \mathrm{~g} \mathrm{~kg}^{-1}$ choline chloride. Supplied by Champion Feed Service Ltd., Westlock, AB

${ }^{5}$ provided the following $\left(\mathrm{kg}^{-1}\right.$ diet): vit. A, 10,000 IU; vit. $\mathrm{D}_{3}, 1,000 \mathrm{IU}$; vit. E, $80 \mathrm{IU}$; vit. $\mathrm{K}: 3,2.0$ mg; vit. Bi2, $0.03 \mathrm{mg}$; riboflavin, $12 \mathrm{mg}$; niacin, $40 \mathrm{mg}$; d-pantothenic acid, $25 \mathrm{mg}$; d-biotin, 0.25 $\mathrm{mg}$; folic acid, $1.6 \mathrm{mg}$; thiamine, $3.0 \mathrm{mg}$; ethoxyquin, $5.0 \mathrm{mg}$; pyridoxine, $2.25 \mathrm{mg}$; Fe, $150 \mathrm{mg}$; $\mathrm{Zn}, 150 \mathrm{mg}$; Cu, $125 \mathrm{mg}$; I, .21 mg; Se, $0.3 \mathrm{mg}$. Supplied by Champion Feed Service Ltd., Westlock, AB

Each experimental period lasted 10 days. Faeces were collected for $48 \mathrm{~h}$ from 08.00 on $\mathrm{d} 6$ to $08.00 \mathrm{~h}$ on $\mathrm{d} 8$. Ileal digesta were collected from 08.00 to $20.00 \mathrm{~h}$ on $\mathrm{d} 8$ and from 20.00 on $\mathrm{d} 9$ to $08.00 \mathrm{~h}$ on $\mathrm{d} 10$. Faeces were collected at $08.00,14.00$ and $20.00 \mathrm{~h}$ and were immediately frozen at $-20^{\circ} \mathrm{C}$ after each collection. Digesta were collected into a plastic bag (length: $20 \mathrm{~cm}$, width: $3 \mathrm{~cm}$ ) that contained $10 \mathrm{~mL} 2.5 \mathrm{M}$ formic acid to minimize bacterial fermentation. The bags were immediately frozen at $-20^{\circ} \mathrm{C}$ when digesta filled approximately one to two thirds of the bags.

The barrows used in this experiment were cared for in accordance with the guidelines established by CCAC (1993) and approved by the Faculty of Agriculture, Forestry and Home Economics Animal Care Committee of the University of Alberta.

\section{In vitro method}

The same barleys and their mixtures as in the in vivo studies were used to determine the digestibility values of dry matter (DM) and energy according to the 
method described by Boisen (1991) but modified as was previously described by Huang et al. (2003).

After the end of the experiment, faeces and digesta were freeze-dried, pooled within barrow and period, and ground through a $0.5-\mathrm{mm}$ mesh screen before analyses. The samples of the diets, ingredients and residues remaining after in vitro incubation were ground similarly. All analyses were performed in duplicate. Analyses for DM, CP, energy, crude fat, and ash were carried out according to AOAC (1990). Energy and CP were determined using the Leco AC-300 Automatic Calorimeter and the Leco FP-428 Nitrogen Analyzer (Leco Corporation, St. Joseph, MT), respectively. Chromic oxide contents in diets, digesta and faeces were measured according to Fenton and Fenton (1979). Neutral detergent fibre (NDF) and acid detergent fibre (ADF) were analysed according to principles outlined by Goering and van Soest (1970). The method for analysis of $\beta$-glucans was previously described by Huang et al. (2003).

For AA analyses, approximately $100 \mathrm{mg}$ of sample was weighed into a screwcapped test tube and mixed with $3 \mathrm{~mL}$ of $6 \mathrm{M} \mathrm{HCl}$ solution. Then, the tubes were purged with nitrogen and hydrolysed in an oven at $110^{\circ} \mathrm{C}$ for $24 \mathrm{~h}$. The hydrolysed samples were mixed with the internal standard, DL-amino-n-butyric acid, and centrifuged at $1,100 \times \mathrm{g}$ for $15 \mathrm{~min}$ at $4^{\circ} \mathrm{C}$. The supernatant of the sample was analysed according to principles outlined by Jones and Gilligan (1983) using a Varian 5000 high performance liquid chromatography system with a reverse-phase column and a Varian Fluorichrom detector (Varian Canada Inc., Mississauga, ON). The amino acids were derivatized with an $o$-phthaldialdehyde reagent solution. The mobile phase consisted of two solvents with a flow rate of $1.1 \mathrm{~mL} / \mathrm{min}$. Solvent A contained $0.1 \mathrm{M}$ sodium acetate ( $\mathrm{pH}$ 7.2), methanol and tetrahydrofuran in a ratio of 90 to 5; Solvent B was pure methanol. Peaks were recorded and integrated using the Ezchrom Chromatography Data System (version 2.12; Shimadzu Scientific Instruments Inc., Columbia, MD). Methionine, cysteine and tryptophan were not determined.

The apparent digestibility values of DM, energy, CP, and AA in the experimental diets were determined using equation (1):

$$
\mathrm{D}_{\mathrm{D}}(\%)=\left[1-\left(\mathrm{I}_{\mathrm{D}} \times \mathrm{A}_{\mathrm{F}}\right) /\left(\mathrm{A}_{\mathrm{D}} \times \mathrm{I}_{\mathrm{F}}\right)\right] \times 100
$$

where $D_{D}$ is the apparent digestibility of a nutrient or energy in the diet $(\%), I_{D}$ is the marker concentration in the $\operatorname{diet}(\%), \mathrm{A}_{\mathrm{F}}$ is the nutrient or energy concentration in ileal digesta or faeces $(\%), \mathrm{A}_{\mathrm{D}}$ is the nutrient or energy concentration in the diet $(\%)$, and $\mathrm{I}_{\mathrm{F}}$ is the marker concentration in ileal digesta or faeces (\%).

By using SBM as the basal feed ingredient, the apparent digestibility values of $\mathrm{CP}, \mathrm{AA}$ and energy in the barleys and their mixtures were calculated by difference using Equation (2): 


$$
\mathrm{D}_{\mathrm{A}}=\left[\mathrm{D}_{\mathrm{D}}-\left(\mathrm{D}_{\mathrm{B}} \times \mathrm{S}_{\mathrm{B}}\right)\right] / \mathrm{S}_{\mathrm{A}}
$$

where $\mathrm{D}_{\mathrm{A}}$ is apparent digestibility of a nutrient or energy in the assay feed ingredient $(\%), D_{D}$ is the apparent digestibility of a nutrient or energy in the assay diet $(\%)$, obtained from equation (1), $\mathrm{D}_{\mathrm{B}}$ is the apparent digestibility of a nutrient or energy in the basal feed ingredient (\%), $\mathrm{S}_{\mathrm{B}}$ is the contribution level (\%) of a nutrient or energy in the basal feed ingredient to the assay diet, and $\mathrm{S}_{\mathrm{A}}$ is the contribution level (\%) of a nutrient or energy in the assay feed ingredient to the assay diet (\%).

Results were subjected to analyses of variance using the General Linear Model Procedure of SAS (1990). The main effects of diets $(n=7)$, pigs $(n=7)$ and periods $(n=7)$ were included in the model. The means of diets were compared using the Student-Newman Keul's multiple range test procedure and the significance level was claimed at $\mathrm{P}<0.05$. Correlation coefficients of faecal DM and energy digestibility values were established between the in vivo and in vitro methods using the Regression Analysis Procedure of SAS (1990). Regression equations were established and accepted if correlations were significant at $\mathrm{P}<0.05$.

\section{RESULTS AND DISCUSSION}

The pigs remained healthy throughout the experiment and readily consumed their daily allowances. Postmortem examinations at the end of the experiment revealed no adhesions or other intestinal abnormalities.

The chemical and amino acid compositions of the dietary ingredients and experimental diets are presented in Tables 2 and 3, respectively. The contents of $\beta$-glucans in the experimental diets were calculated from the analysed values in barley and SBM. The values of all other parameters analysed in the experimental diets were very close to the calculated values based on the analysed values in the dietary ingredients. The values of the parameters measured in barley and SBM were in the range of those reported by NRC (1998) and Jaikaran et al. (1998). The $\mathrm{CP}$ content in hulless barley is usually higher than in hulled barley (Jaikaran et al., 1998) which was also the case in this study. The CP contents in hulless barley were 12.7 and $12.4 \%$, and 9.7 and $11.4 \%$ in hulled barley (Table 2). The $\beta$-glucan contents were also higher in hulless (4.46 and 4.33\%) than in hulled barley (3.84 and $3.78 \%$ ). In agreement with results reported by Newman et al. (1989), hulless barley usually has a higher B-glucan content than hulled barley.

The apparent ileal digestibility values of DM, CP and AA in the experimental diets are presented in Table 4. The apparent ileal digestibility values of CP and AA in the SBM diet are in the range of those reported by Knabe et al. (1989) and NRC (1998). As expected, the apparent ileal digestibility values of DM, CP and most of the AA in the SBM diet were higher $(\mathrm{P}<0.05)$ than in the barley-containing diets. 
TABLE 2

Chemical and amino acid composition of the ingredients, $\mathrm{g} \mathrm{kg}^{-1}$ as-fed basis

\begin{tabular}{|c|c|c|c|c|c|c|c|}
\hline \multirow{2}{*}{ Items } & \multicolumn{7}{|c|}{ Ingredients $^{1}$} \\
\hline & SBM & A & B & $\mathrm{C}$ & $\mathrm{D}$ & $\mathrm{E}$ & $\mathrm{F}$ \\
\hline Dry matter & 886.0 & 887.0 & 884.0 & 879.0 & 879.0 & 887.0 & 881.0 \\
\hline Gross energy, $\mathrm{MJ} \mathrm{kg}^{-1}$ & 17.6 & 16.6 & 16.7 & 17.5 & 17.2 & 17.1 & 16.9 \\
\hline Crude fat & 11.4 & 19.8 & 19.2 & 21.7 & 19.0 & 21.6 & 20.4 \\
\hline Neutral detergent fibre & 83.6 & 139.5 & 139.6 & 92.9 & 95.5 & 115.0 & 118.0 \\
\hline Acid detergent fibre & 42.6 & 43.8 & 42.1 & 19.8 & 14.7 & 32.0 & 28.8 \\
\hline Ash & 62.7 & 20.4 & 18.4 & 19.4 & 17.5 & 19.9 & 18.0 \\
\hline ß-glucans & 1.1 & 38.4 & 37.8 & 44.6 & 43.3 & 41.6 & 40.4 \\
\hline Crude protein & 461.0 & 97.0 & 114.0 & 127.0 & 124.0 & 112.0 & 118.0 \\
\hline \multicolumn{8}{|l|}{ Amino acids } \\
\hline \multicolumn{8}{|l|}{ Indispensable } \\
\hline histidine & 12.9 & 2.6 & 2.8 & 3.0 & 2.5 & 2.8 & 2.6 \\
\hline isoleucine & 23.5 & 4.3 & 4.8 & 5.0 & 5.1 & 4.6 & 4.8 \\
\hline leucine & 35.1 & 7.4 & 8.4 & 8.8 & 8.9 & 8.0 & 8.6 \\
\hline lysine & 28.8 & 3.8 & 4.1 & 4.7 & 4.8 & 4.3 & 4.4 \\
\hline phenylalanine & 22.1 & 5.1 & 6.2 & 6.3 & 6.1 & 5.7 & 6.1 \\
\hline threonine & 17.4 & 3.6 & 3.7 & 4.2 & 4.2 & 3.8 & 3.9 \\
\hline valine & 22.9 & 5.6 & 6.0 & 6.4 & 6.4 & 6.2 & 6.2 \\
\hline \multicolumn{8}{|l|}{ Dispensable } \\
\hline alanine & 19.2 & 4.2 & 4.6 & 5.1 & 4.9 & 4.7 & 4.8 \\
\hline aspartic acid & 49.7 & 5.7 & 6.5 & 7.3 & 7.3 & 6.9 & 7.1 \\
\hline glutamic acid & 80.0 & 21.8 & 26.7 & 29.4 & 29.1 & 27.1 & 28.3 \\
\hline glycine & 22.6 & 4.8 & 5.1 & 5.3 & 5.6 & 5.0 & 5.3 \\
\hline serine & 18.7 & 3.4 & 4.1 & 4.5 & 4.5 & 4.1 & 4.2 \\
\hline tyrosine & 10.6 & 2.3 & 2.7 & 2.8 & 3.0 & 2.6 & 2.8 \\
\hline
\end{tabular}

${ }^{1}$ SBM: soyabean meal; A: hulled barley (c.v. Harrington I); B: hulled barley (c.v. Harrington II); C: hulless barley (c.v. CDC Buck I); D: hulless barley (c.v. CDC Buck II); E: mixture of c.v. Harrington I and c.v. CDC Buck I (50:50 wt/wt); F: mixture of c.v. Harrington II and c.v. CDC Buck II (50:50 wt/wt)

The apparent digestibility values of $\mathrm{CP}$ and most of the AA were higher $(\mathrm{P}<0.05)$ in the diets containing hulled compare to hulless barley. The values of the diets containing the barley mixtures were intermediate.

The apparent ileal digestibility values of $\mathrm{CP}$ and AA in barley, determined by the difference method, are presented in Table 5. The values are in the range of those reported by Sauer et al. (1981), Buraczewska et al. (1987), Fan and Sauer (1995), Baidoo and Liu (1998) and Huang et al. (1998) for hulless and hulled barleys. Of the aforementioned authors only Fan and Sauer (1995) and Huang et al. (1998) used the difference method, which should be the method of choice (or regression method) for determining amino acid digestibility values in feedstuffs low in protein, such as barley (Sauer et al., 2001). The apparent digestibi- 
TABLE 3

Chemical and amino acid composition of the experimental diets, $\mathrm{g} \mathrm{kg}^{-1}$ as-fed basis

\begin{tabular}{lrrrrrrr}
\hline \multirow{2}{*}{ Items } & \multicolumn{7}{c}{ Diets ${ }^{1}$} \\
\cline { 2 - 7 } & $\mathrm{SBM}$ & \multicolumn{1}{c}{$\mathrm{A}$} & \multicolumn{1}{c}{$\mathrm{B}$} & \multicolumn{1}{c}{$\mathrm{C}$} & $\mathrm{D}$ & \multicolumn{1}{c}{$\mathrm{E}$} & $\mathrm{F}$ \\
\hline Dry matter & 899.0 & 894.0 & 894.0 & 892.0 & 895.0 & 894.0 & 894.0 \\
Gross energy, $\mathrm{MJ} \mathrm{kg}^{-1}$ & 16.5 & 17.2 & 17.0 & 17.0 & 17.0 & 17.0 & 17.0 \\
Crude fat & 34.4 & 48.4 & 46.3 & 49.9 & 48.4 & 49.0 & 47.6 \\
Neutral detergent fibre & 32.9 & 119.0 & 116.8 & 86.4 & 88.2 & 103.0 & 104.7 \\
Acid detergent fibre & 16.8 & 41.1 & 39.9 & 22.6 & 18.9 & 32.4 & 29.5 \\
Ash & 45.6 & 50.0 & 49.2 & 48.1 & 46.1 & 50.0 & 47.8 \\
B-glucans & 0.4 & 27.7 & 28.2 & 34.7 & 33.5 & 31.1 & 30.8 \\
Crude protein & 174.0 & 176.0 & 180.0 & 179.0 & 176.0 & 172.0 & 176.0 \\
& & & & & & & \\
Amino acids & & & & & & & \\
Indispensable & & & & & & & \\
$\quad$ arginine & 11.7 & 9.1 & 8.2 & 8.9 & 9.7 & 9.3 & 9.2 \\
$\quad$ histidine & 5.1 & 4.1 & 4.0 & 3.9 & 4.5 & 4.0 & 4.2 \\
$\quad$ isoleucine & 9.3 & 8.1 & 7.6 & 7.6 & 7.8 & 8.1 & 7.9 \\
$\quad$ leucine & 13.8 & 13.9 & 12.8 & 12.7 & 13.1 & 13.4 & 13.2 \\
$\quad$ lysine & 11.3 & 9.4 & 9.0 & 8.6 & 8.9 & 9.0 & 9.0 \\
$\quad$ phenylalanine & 8.7 & 9.1 & 8.9 & 8.9 & 9.1 & 9.1 & 9.0 \\
$\quad$ threonine & 6.9 & 6.6 & 6.1 & 6.2 & 6.0 & 5.8 & 5.8 \\
$\quad$ valine & 9.0 & 8.9 & 8.2 & 9.1 & 9.6 & 9.4 & 9.2 \\
Dispensable & & & & & & & \\
$\quad$ alanine & 7.5 & 7.5 & 6.9 & 7.5 & 7.8 & 7.8 & 7.7 \\
$\quad$ aspartic acid & 19.6 & 16.3 & 14.4 & 14.8 & 16.4 & 15.7 & 15.7 \\
glutamic acid & 31.5 & 36.6 & 35.5 & 38.8 & 41.1 & 38.3 & 39.0 \\
glycine & 8.9 & 7.6 & 7.5 & 7.5 & 7.7 & 7.7 & 7.6 \\
$\quad$ serine & 7.4 & 6.3 & 5.7 & 6.4 & 7.1 & 6.5 & 6.5 \\
$\quad$ tyrosine & 4.2 & 3.8 & 3.6 & 4.4 & 4.6 & 4.1 & 4.6 \\
\hline
\end{tabular}

${ }^{1}$ refer to Table 1

lity values of lysine (first-limiting AA in barley) and threonine (second-limiting) ranged from 58.2 to $69.7 \%$ and from 53.7 to $59.6 \%$, respectively, in this study. In the same order for these AA, the values reported by Fan and Sauer (1995) were 62.4 and $61.3 \%$ in studies with growing pigs. Huang et al. (1998), in studies with young pigs, reported values of 56.1 and $55.6 \%$ for lysine and threonine, respectively. It should be pointed out that it is rather difficult to directly compare apparent amino acid digestibility values in barley with those reported in other publications from the literature. As was reviewed by Sauer et al. (2001), differences in apparent ileal amino acid digestibility values in barley may be attributed to differences in processing and other factors including variety, fertilizer application and environmental conditions. Processing of barley, in particular, may affect amino acid digestibility values. As was shown in the original studies by Wünsche et al. (1987), the apparent ileal digestibility values of lysine, the limiting AA in barley, were 43.6, 54.2, and 63.0\% in coarsely, medium, and finely ground barley, respectively. 
TABLE 4

The apparent ileal digestibility values of dry matter, crude protein, and amino acids of the experimental diets, \%

\begin{tabular}{|c|c|c|c|c|c|c|c|c|}
\hline \multirow{2}{*}{ Items } & \multicolumn{7}{|c|}{ Diets $^{1}$} & \multirow{2}{*}{ SEM } \\
\hline & SBM & A & B & $\mathrm{C}$ & D & $\mathrm{E}$ & $\mathrm{F}$ & \\
\hline Dry matter & $73.6^{\mathrm{a}}$ & $59.2^{\mathrm{b}}$ & $59.7^{\mathrm{b}}$ & $61.3^{\mathrm{b}}$ & $61.5^{\mathrm{b}}$ & $59.2^{\mathrm{b}}$ & $59.3^{\mathrm{b}}$ & 1.25 \\
\hline Crude protein & $80.6^{a}$ & $75.4^{\mathrm{b}}$ & $75.6^{\mathrm{b}}$ & $71.7^{\mathrm{c}}$ & $70.7^{\mathrm{c}}$ & $72.7^{\mathrm{c}}$ & $71.2^{\mathrm{c}}$ & 0.81 \\
\hline \multicolumn{9}{|l|}{ Amino acids } \\
\hline \multicolumn{9}{|l|}{ Indispensable } \\
\hline arginine & $90.9^{\mathrm{a}}$ & $85.7^{\mathrm{b}}$ & $84.8^{\mathrm{bc}}$ & $81.2^{\mathrm{d}}$ & $80.8^{\mathrm{d}}$ & $83.0^{\mathrm{cd}}$ & $82.6^{\mathrm{cd}}$ & 0.89 \\
\hline histidine & $89.8^{\mathrm{a}}$ & $84.1^{\mathrm{b}}$ & $82.8^{\mathrm{b}}$ & $81.4^{\mathrm{b}}$ & $82.0^{\mathrm{b}}$ & $83.3^{\mathrm{b}}$ & $82.3^{\mathrm{b}}$ & 1.02 \\
\hline isoleucine & $88.9^{\mathrm{a}}$ & $84.4^{\mathrm{b}}$ & $82.4^{\mathrm{bc}}$ & $75.9^{\mathrm{d}}$ & $76.0^{\mathrm{d}}$ & $78.0^{\mathrm{cd}}$ & $78.9^{\mathrm{cd}}$ & 1.42 \\
\hline leucine & $87.1^{\mathrm{a}}$ & $82.2^{\mathrm{b}}$ & $80.5^{\mathrm{bc}}$ & $76.3^{\mathrm{d}}$ & $76.1^{\mathrm{d}}$ & $77.8^{\mathrm{cd}}$ & $77.4^{\mathrm{d}}$ & 1.08 \\
\hline lysine & $87.4^{\mathrm{a}}$ & $82.3^{\mathrm{b}}$ & $79.0^{\mathrm{c}}$ & $75.0^{\mathrm{d}}$ & $75.7^{\mathrm{cd}}$ & $77.7^{\mathrm{c}}$ & $76.2^{\mathrm{cd}}$ & 0.98 \\
\hline phenylalanine & $87.4^{\mathrm{a}}$ & $83.1^{\mathrm{b}}$ & $81.4^{\mathrm{bc}}$ & $78.5^{\mathrm{c}}$ & $78.2^{\mathrm{c}}$ & $79.4^{\mathrm{bc}}$ & $79.0^{\mathrm{c}}$ & 1.12 \\
\hline threonine & $82.9^{\mathrm{a}}$ & $73.0^{\mathrm{b}}$ & $72.8^{\mathrm{bc}}$ & $67.7^{\mathrm{d}}$ & $69.0^{\mathrm{cd}}$ & $70.1^{\text {bed }}$ & $70.2^{\mathrm{d}}$ & 1.10 \\
\hline valine & $83.2^{\mathrm{a}}$ & $81.2^{\mathrm{ab}}$ & $78.3^{\mathrm{bc}}$ & $74.7^{\mathrm{c}}$ & $74.9^{\mathrm{c}}$ & $76.7^{\mathrm{bc}}$ & $76.2^{\mathrm{c}}$ & 1.57 \\
\hline \multicolumn{9}{|l|}{ Dispensable } \\
\hline alanine & $82.5^{\mathrm{a}}$ & $74.1^{\mathrm{b}}$ & $71.6^{\mathrm{bc}}$ & $68.6^{\mathrm{c}}$ & $70.1^{\mathrm{c}}$ & $71.3^{\mathrm{bc}}$ & $70.2^{\mathrm{c}}$ & 0.98 \\
\hline aspartic acid & $83.6^{\mathrm{a}}$ & $78.8^{\mathrm{b}}$ & $76.2^{\mathrm{bc}}$ & $74.0^{c}$ & $74.7^{\mathrm{c}}$ & $75.6^{\mathrm{bc}}$ & $75.3^{\mathrm{c}}$ & 1.02 \\
\hline glutamic acid & $84.4^{\mathrm{a}}$ & $82.8^{\mathrm{ab}}$ & $82.7^{\mathrm{ab}}$ & $79.3^{\mathrm{c}}$ & $80.9^{\mathrm{bc}}$ & $82.9^{\mathrm{ab}}$ & $82.2^{\mathrm{abc}}$ & 0.91 \\
\hline glycine & $74.3^{\mathrm{a}}$ & $68.7^{\mathrm{b}}$ & $68.1^{\mathrm{b}}$ & $61.5^{\text {cd }}$ & $58.8^{\mathrm{d}}$ & $64.3^{\mathrm{bc}}$ & $62.7^{\mathrm{cd}}$ & 1.62 \\
\hline serine & $81.2^{\mathrm{a}}$ & $74.5^{b}$ & $70.5^{\mathrm{c}}$ & $72.3^{\text {bc }}$ & $74.8^{\mathrm{b}}$ & $73.7^{\mathrm{b}}$ & $72.5^{\mathrm{bc}}$ & 1.01 \\
\hline tyrosine & $86.1^{\mathrm{a}}$ & $79.3^{\mathrm{b}}$ & $77.6^{\mathrm{b}}$ & $78.4^{\mathrm{b}}$ & $79.4^{\mathrm{b}}$ & $78.6^{\mathrm{b}}$ & $79.5^{\mathrm{b}}$ & 0.90 \\
\hline
\end{tabular}

${ }^{1}$ refer to Table 1

a, b, c, d means in the same row with different superscript letters differ at $\mathrm{P}<0.05(\mathrm{n}=7)$

TABLE 5

The apparent ileal digestibility values of dry matter, crude protein, and amino acids of the barleys and their mixtures, $\%$

\begin{tabular}{|c|c|c|c|c|c|c|c|}
\hline \multirow{2}{*}{ Items } & \multicolumn{6}{|c|}{ Barleys and mixtures ${ }^{1}$} & \multirow[b]{2}{*}{ SEM } \\
\hline & A & B & $\mathrm{C}$ & $\mathrm{D}$ & $\mathrm{E}$ & $\mathrm{F}$ & \\
\hline Dry matter & 54.5 & 55.8 & 58.6 & 58.7 & 55.0 & 55.6 & 1.12 \\
\hline Crude protein & $67.3^{\mathrm{a}}$ & $70.0^{\mathrm{a}}$ & $64.5^{\mathrm{b}}$ & $62.1^{\mathrm{b}}$ & $66.7^{\mathrm{ab}}$ & $64.8^{\mathrm{b}}$ & 0.92 \\
\hline \multicolumn{8}{|l|}{ Amino acids } \\
\hline \multicolumn{8}{|l|}{ Indispensable } \\
\hline histidine & 74.9 & 73.8 & 73.4 & 72.6 & 73.8 & 72.5 & 1.01 \\
\hline isoleucine & $76.4^{\mathrm{a}}$ & $73.5^{\mathrm{a}}$ & $62.4^{\mathrm{c}}$ & $62.2^{\mathrm{c}}$ & $63.3^{\mathrm{bc}}$ & $66.4^{\mathrm{b}}$ & 1.32 \\
\hline leucine & $74.6^{\mathrm{a}}$ & $72.8^{\mathrm{ab}}$ & $66.7^{\mathrm{c}}$ & $66.0^{\mathrm{c}}$ & $70.4^{\mathrm{bc}}$ & $67.3^{\mathrm{c}}$ & 0.98 \\
\hline lysine & $69.7^{\mathrm{a}}$ & $62.6^{\mathrm{b}}$ & $58.2^{\mathrm{c}}$ & $59.4^{\mathrm{c}}$ & $62.0^{\mathrm{b}}$ & $60.5^{\mathrm{bc}}$ & 0.92 \\
\hline phenylalanine & $77.0^{\mathrm{a}}$ & $75.4^{\mathrm{a}}$ & $71.6^{\mathrm{b}}$ & $70.4^{\mathrm{b}}$ & $73.8^{\mathrm{ab}}$ & $71.2^{\mathrm{b}}$ & 1.05 \\
\hline threonine & $57.4^{\mathrm{a}}$ & $59.6^{\mathrm{ab}}$ & $53.7^{\mathrm{c}}$ & $55.6^{\mathrm{c}}$ & $55.8^{\mathrm{bc}}$ & $57.4^{\mathrm{ab}}$ & 1.01 \\
\hline valine & $78.5^{\mathrm{a}}$ & $73.1^{\mathrm{a}}$ & $68.0^{\mathrm{b}}$ & $68.0^{\mathrm{b}}$ & $69.1^{\mathrm{b}}$ & $69.6^{\mathrm{ab}}$ & 1.32 \\
\hline \multicolumn{8}{|l|}{ Dispensable } \\
\hline alanine & $61.6^{\mathrm{a}}$ & $58.9^{\mathrm{b}}$ & $57.0^{\mathrm{b}}$ & $58.8^{\mathrm{b}}$ & $57.7^{\mathrm{b}}$ & $58.6^{\mathrm{b}}$ & 0.96 \\
\hline aspartic acid & $65.1^{\mathrm{a}}$ & $60.5^{\mathrm{b}}$ & $59.5^{\mathrm{b}}$ & $60.6^{\mathrm{b}}$ & $60.9^{\mathrm{b}}$ & $60.5^{\mathrm{b}}$ & 1.02 \\
\hline glutamic acid & $82.7^{\mathrm{a}}$ & $79.3^{\mathrm{b}}$ & $77.2^{\mathrm{bc}}$ & $79.7^{\mathrm{b}}$ & $82.2^{\mathrm{ab}}$ & $79.8^{\mathrm{b}}$ & 1.05 \\
\hline glycine & $60.1^{\mathrm{a}}$ & $60.5^{\mathrm{a}}$ & $49.4^{b}$ & $44.2^{\mathrm{c}}$ & $50.8^{\mathrm{b}}$ & $50.1^{\mathrm{b}}$ & 1.59 \\
\hline serine & $64.1^{\mathrm{b}}$ & $68.6^{\mathrm{c}}$ & $62.5^{\mathrm{b}}$ & $56.9^{\mathrm{a}}$ & $63.4^{\mathrm{b}}$ & $62.6^{\mathrm{b}}$ & 0.95 \\
\hline tyrosine & 71.9 & 73.9 & 69.1 & 68.3 & 70.9 & 73.1 & 1.22 \\
\hline
\end{tabular}

${ }^{1}$ refer to footnote 1 of Table 2

a, b, c means in the same row with different superscript letters differ at $\mathrm{P}<0.05(\mathrm{n}=7)$ 
As shown in Table 5, the apparent ileal digestibility values of CP and AA were usually higher in hulled than in hulless barley; the values of the barley mixtures were intermediate. Of the indispensable AA, with the exception of histidine, the differences were significant $(\mathrm{P}<0.05)$. The lower apparent AA digestibilities in hulless than in hulled barley can perhaps be attributed to their higher content of $\beta$-glucans, even though the differences in $\beta$-glucan contents were relatively small. The $\beta$-glucan contents in the hulless barleys were 4.46 and $4.33 \%$; the contents in the hulled barleys were 3.84 and $3.78 \%$ (Table 2). The negative impact of $\beta$ glucans on protein digestion and amino acid absorption is supported by results reported by $\mathrm{Li}$ et al. (1996) who showed that $\beta$-glucanase supplementation to hulless barley-based diets for growing pigs improved the apparent ileal CP and AA digestibility values. The mechanism by which $\beta$-glucans interfere with digestion of protein and absorption of AA are closely related to their physico-chemical properties. $\beta$-glucans contain approximately $30 \%$ of the linkages in the form of $\beta$ (1-3) and $70 \%$ in the form of $\beta$ (1-4) between glucose molecules. This branched structure prevents compact folding of the molecules and increases the water-holding capacity, which results in its characteristic viscosity and gelling properties (Wang et al., 1992). The viscosity and gelling properties tend to hinder motility of digesta in the small intestine, thereby decreasing the mixing of digesta with digestive enzymes and other necessary components required for digestion and absorption (Wang et al., 1992). These properties may also delay or decrease digestion and absorption of nutrients by increasing the thickness of the unstirred fluid layer, creating a physical barrier at the absorption surface on the microvilli (Johnson and Gee, 1981).

The faecal digestibility values of DM, energy and CP in the experimental diets are presented in Table 6 . As expected, the faecal digestibility values of the parameters measured were highest for the SBM diet. The faecal digestibility values of $\mathrm{DM}$ and energy were higher $(\mathrm{P}<0.05)$ in the diets containing hulless barley than in the diets containing hulled barley. There were no differences $(\mathrm{P}<0.05)$ in the $\mathrm{CP}$ digestibility values among the barley-SBM diets.

The faecal digestibility values of DM, energy and CP in the barleys and their mixtures, calculated by difference, are also presented in Table 6 . As expected, the faecal DM and energy digestibility values were higher $(\mathrm{P}<0.05)$ in the hulless than in the hulled barleys, which is in agreement with results previously reported by Huang et al. (2003). The digestibility values of DM and energy in the mixtures of barley were intermediate. There were no differences $(P>0.05)$ in faecal $\mathrm{CP}$ digestibility values between the hulled and hulless barleys. This study shows once more that the ileal analysis method is more sensitive than the faecal analysis method for determining differences in digestibility values between feedstuffs as was previously reviewed by Sauer and Ozimek (1986). The apparent ileal CP digestibility values in the hulless barleys were lower $(\mathrm{P}<0.05)$ than in the hulled 
TABLE 6

The apparent faecal digestibility values of dry matter, energy, and crude protein of the experimental diets and the barleys and their mixtures, in addition to their in vitro values for dry matter and energy, $\%$

\begin{tabular}{|c|c|c|c|c|c|c|c|c|}
\hline \multirow{2}{*}{ Items } & \multicolumn{7}{|c|}{ Diets $^{1}$} & \multirow[b]{2}{*}{ SEM } \\
\hline & SBM & A & B & $\mathrm{C}$ & D & E & $\mathrm{F}$ & \\
\hline \multicolumn{9}{|l|}{ In vivo } \\
\hline Dry matter & $93.4^{\mathrm{a}}$ & $83.2^{\mathrm{f}}$ & $83.8^{\mathrm{e}}$ & $87.7^{\mathrm{c}}$ & $88.7^{\mathrm{b}}$ & $84.9^{\mathrm{d}}$ & $85.2^{\mathrm{d}}$ & 0.23 \\
\hline Energy & $94.3^{\mathrm{a}}$ & $83.4^{\mathrm{e}}$ & $83.7^{\mathrm{e}}$ & $87.3^{\mathrm{c}}$ & $88.2^{\mathrm{b}}$ & $84.8^{\mathrm{d}}$ & $85.0^{\mathrm{d}}$ & 0.25 \\
\hline \multirow[t]{3}{*}{ Crude protein } & $92.4^{\mathrm{a}}$ & $86.3^{\mathrm{b}}$ & $87.4^{\mathrm{b}}$ & $87.0^{\mathrm{b}}$ & $87.2^{\mathrm{b}}$ & $86.6^{\mathrm{b}}$ & $87.6^{\mathrm{b}}$ & 0.3 \\
\hline & \multicolumn{8}{|c|}{ Ingredients $^{2}$} \\
\hline & & A & B & $\mathrm{C}$ & $\mathrm{D}$ & E & $\mathrm{F}$ & SEM \\
\hline \multicolumn{9}{|l|}{ In vivo } \\
\hline Dry matter & & $79.9^{\mathrm{e}}$ & $81.1^{\mathrm{d}}$ & $86.4^{\mathrm{b}}$ & $87.6^{\mathrm{a}}$ & $82.3^{\mathrm{c}}$ & $82.9^{\mathrm{c}}$ & 0.22 \\
\hline Energy & & $79.8^{\mathrm{d}}$ & $80.7^{\mathrm{d}}$ & $85.7^{\mathrm{b}}$ & $86.8^{\mathrm{a}}$ & $82.2^{\mathrm{c}}$ & $82.6^{\mathrm{c}}$ & 0.23 \\
\hline Crude protein & & 78.0 & 80.5 & 83.8 & 81.1 & 80.7 & 80.5 & 1.15 \\
\hline \multicolumn{9}{|l|}{ In vitro } \\
\hline Dry matter & & $86.7^{\mathrm{c}}$ & $87.3^{\mathrm{c}}$ & $92.1^{\mathrm{a}}$ & $92.8^{\mathrm{a}}$ & $90.1^{\mathrm{b}}$ & $90.3^{b}$ & 0.25 \\
\hline Energy & & $83.5^{\mathrm{e}}$ & $85.0^{\mathrm{d}}$ & $88.3^{\mathrm{ab}}$ & $89.0^{\mathrm{a}}$ & $86.8^{\mathrm{c}}$ & $87.4^{\mathrm{bc}}$ & 0.46 \\
\hline
\end{tabular}

${ }^{1}$ refer to Table 1

${ }^{2}$ refer to footnote 1 of Table 2

$\mathrm{a}, \mathrm{b}, \mathrm{c}, \mathrm{d}, \mathrm{e}, \mathrm{f}$ means in the same row with different superscript letters differ at $\mathrm{P}<0.05$

TABLE 7

The linear relationships between the in vivo and in vitro values for dry matter and energy digestibility and digestible energy content in the barleys and their mixtures

\begin{tabular}{lccc}
\hline Item & \multicolumn{1}{c}{ Equations $^{\mathrm{a}, \mathrm{b}}$} & $\mathrm{R}^{2}$ & $\mathrm{P}_{\text {value }}^{\mathrm{c}}$ \\
\hline $\begin{array}{l}\text { Present study }(\mathrm{n}=6) \\
\text { Dry matter, \% } \\
\text { Energy, \% }\end{array}$ & $\mathrm{Y}_{\text {in vivo }}=1.17 \mathrm{X}_{\text {in vitro }}-21.54$ & 0.91 & 0.0032 \\
$\begin{array}{c}\mathrm{Y}_{\text {in vivo }}=1.25 \mathrm{X}_{\text {in vitro }}-25.37 \\
\text { Combined studies }(\mathrm{n}=12)^{\mathrm{d}}\end{array}$ & $\mathrm{Y}_{\text {in vivo }}=0.94 \mathrm{X}_{\text {in vitro }}+1.95$ & 0.88 & 0.0055 \\
$\begin{array}{l}\text { Energy, \% } \\
\text { Energy, MJ kg-1 }\end{array}$ & $\mathrm{Y}_{\text {in vivo }}=0.98 \mathrm{X}_{\text {in vitro }}-0.33$ & 0.90 & 0.0025 \\
\hline
\end{tabular}

${ }^{a} \mathrm{Y}=$ digestibility values, $\%$ or digestible energy content $\left(\mathrm{MJ} \mathrm{kg}^{-1}\right)$ with the in vivo method

${ }^{\mathrm{b}} \mathrm{X}=$ digestibility values, $\%$ or digestible energy content $\left(\mathrm{MJ} \mathrm{kg}^{-1}\right)$ with the in vitro method

${ }^{c}$ the probability of significance for the slope of the regression equation

${ }^{d}$ combined results from this study and of Huang et al. (2003)

barleys (Table 4) but there were no differences $(\mathrm{P}>0.05)$ when these were determined with the faecal analysis method (Table 6).

Following the completion of the in vivo studies, in vitro studies were carried out to determine the DM and energy digestibilities. The in vitro values were higher than the in vivo values (Table 6). For energy, the differences ranged from 2.6 to 4.8 percentage units. Possible explanations for the differences were given previously 
(Huang et al., 2003). As was the case in the studies by Huang et al. (2003), the in vitro method was able to distinguish between and within hulled and hulless barley for differences in energy digestibility. As shown in Table 7, there were close correlations between the in vivo and in vitro digestibility values for energy $\left(\mathrm{r}^{2}=0.88\right)$ and DM $\left(r^{2}=0.91\right)$, in agreement with previous studies (Huang et al., 2003). The results obtained in this study and in the previous study (Huang et al., 2003) were combined in order to establish a linear relationship equation with more data points $(\mathrm{n}=12)$, which gave an $\mathrm{R}^{2}$ value of 0.90 . In addition, a linear regression equation was established between the in vivo and in vitro digestible energy content, which gave a very high $\mathrm{r}^{2}$ value, namely 0.94 .

The digestible contents of energy and apparent digestible faecal and ileal contents of crude protein and indispensable amino acids are summarized in Table 8. The digestible energy contents in the hulled barleys ranged from 13.2 to $13.4 \mathrm{MJ}$ $\mathrm{kg}^{-1}$; in the hulless barleys from 14.9 to $15.0 \mathrm{MJ} \mathrm{kg}^{-1}$. Although the apparent ileal $\mathrm{CP}$ and AA digestibility values were lower $(\mathrm{P}<0.05)$ in hulless than in hulled barley (Table 5), the digestible contents were similar or higher in hulless barley for reasons of its higher $\mathrm{CP}$ and $\mathrm{AA}$ content.

TABLE 8

The digestible contents of energy $\left(\mathrm{MJ} \mathrm{kg}^{-1}\right)$ and apparent digestible faecal and ileal contents of crude protein and indispensable amino acids $\left(\mathrm{g} \mathrm{kg}^{-1}\right)$ in hulled and hulless barleys, as-fed

\begin{tabular}{lccrr}
\hline \multirow{2}{*}{ Items } & \multicolumn{3}{c}{ Barleys $^{1}$} \\
\cline { 2 - 5 } & $\mathrm{A}$ & $\mathrm{B}$ & $\mathrm{C}$ & \multicolumn{1}{c}{$\mathrm{D}$} \\
\hline Digestible energy $^{2}$ & 13.2 & 13.4 & 15.0 & 14.9 \\
Digestible crude protein $^{2}$ & 75.7 & 91.8 & 106.4 & 100.6 \\
Digestible crude protein $^{3}$ & 65.3 & 79.8 & 81.9 & 77.0 \\
Digestible amino acids & & & & \\
$\quad$ Indispensable & & & & \\
$\quad$ arginine & 3.8 & 3.7 & 3.6 & 3.5 \\
$\quad$ histidine & 1.9 & 2.1 & 2.2 & 1.8 \\
$\quad$ isoleucine & 3.3 & 3.5 & 3.1 & 3.2 \\
$\quad$ leucine & 5.5 & 6.1 & 5.9 & 5.9 \\
$\quad$ lysine & 2.6 & 2.6 & 2.7 & 2.9 \\
$\quad$ phenylalanine & 3.9 & 4.7 & 4.5 & 4.3 \\
$\quad$ threonine & 2.1 & 2.2 & 2.3 & 2.3 \\
$\quad$ valine & 4.4 & 4.4 & 4.4 & 4.4 \\
\hline
\end{tabular}

${ }^{1}$ refer to footnote of Table 2

${ }^{2}$ faecal analysis method

${ }^{3}$ ileal analysis method 


\section{REFERENCES}

AOAC, 1995. Official Methods of Analysis, Association of Official Analytical Chemists. $16^{\text {th }}$ Edition. Arlington, VA

Baidoo S.K., Liu Y.G., 1998. Hull-less barley for swine: ileal and faecal digestibility of proximate nutrients, amino acids and non-starch polysaccharides. J. Sci. Food Agr. 76, 397-403

Boisen S., 1991. A model for feed evaluation based on in vitro digestible dry matter and protein. In: M.F. Fuller (Editor). In Vitro Digestion for Pigs and Poultry. C.A.B. International, Wallingford (UK), pp. 135-145

Buraczewska L., Schulz E., Schröder H., 1987. Ileal digestibility of amino acids in pigs fed barleys differing in protein content. Arch. Anim. Nutr. (Berlin) 37, 861-867

CCAC, 1993. Canadian Council on Animal Care. Guide to the Care and Use of Experimental Animals. Vol. 1 (with addendum). Ottawa, ON (Canada)

De Lange C.F.M., Sauer W.C., Mosenthin R., Souffrant W.B., 1989. The effect of feeding different protein-free diets on the recovery and amino acid composition of endogenous protein collected from the distal ileum and feces in pigs. J. Anim. Sci. 67, 746-754

Fan M.Z., Sauer W.C., 1995. Determination of apparent ileal amino acid digestibility in barley and canola meal for pigs with the direct, difference, and regression methods. J. Anim. Sci. 73, 2364-2374

Fenton T.W., Fenton M., 1979. An improved procedure for the determination of chromic oxide in feed and feces. Can. J. Anim. Sci. 59, 631-634

Goering H.K., van Soest P.J., 1970. Forage Fiber Analyses (Apparatus, Reagents, Procedures, and some Application). Agric. Handbook No. 379. ARS, USDA, Washington, DC

Huang G., Sauer W.C, He J., Hwangbo J., Wang X., 2003. The nutritive value of hulled and hulless barley for growing pigs. 1. Determination of energy and protein digestibility with the in vivo and in vitro method. J. Anim. Feed Sci. 12, 759-769

Huang S.X., Sauer W.C., Pickard M., Hardin R.T., 1998. Effect of micronization on energy, starch, and amino acid digestibility in hulless barley for young pigs. Can. J. Anim. Sci. 78, 81-87

Jaikaran S., Recinos Diaz G., Hsu H., Prommer E.A., 1998. NIRS predictions for amino acids in whole and ground barley. In: Measuring the Feeding Quality of Barley Grain. $2^{\text {nd }}$ Feed Grain Quality Conference, Edmonton (Canada), pp. 82-92

Johnson I.T., Gee J.M., 1981. Effect of gel-forming gums on the intestinal unstirred water layer and sugar transport in vitro. Gut 22, 398-404

Jones B.N., Gilligan J.P., 1983. o-phthaldialdehyde precolumn derivatization and reverse-phase high performance liquid chromatography of polypeptide hydrolysates and physiological fluids. J. Chromatogr. 266, 471-482

Knabe D.A., LaRue D.C., Gregg E.J., Martinez G.M., Tanksley T.D. Jr., 1989. Apparent digestibility of nitrogen and amino acids in protein feedstuffs for growing pigs. J. Anim. Sci. 67, 441-458

Li S., Sauer W.C., Hardin R.T., 1994. Effect of dietary fiber level on amino acid digestibility in young pigs. Can. J. Anim. Sci. 74, 327-333

Li S., Sauer W.C., Huang S.X., Gabert V.M., 1996. Effect of $\beta$-glucanase supplementation to hulless barley- or wheat-soybean meal diets on the digestibilities of energy, protein, $\beta$-glucans and amino acids in young pigs. J. Anim. Sci. 74, 1649-1656

Newman P.K., Lewis S.E., Newman C.W., Boik R.J., Ramage R.E., 1989. Hypocholesterolemic effect of barley foods on healthy men. Nutr. Rep. Int. 39, 749-760

NRC, 1998. National Research Council. Nutrient Requirements of Swine. $10^{\text {th }}$ Edition. National Academy Press, Washington, DC

SAS, 1990. SAS/STAT ${ }^{\text {TM }}$ User's Guide (Version 6, $4^{\text {th }}$ Ed.). SAS Inst. Inc., Cary, NC 
Sauer W.C., Fan M.Z., Mosenthin R., Drochner W., 2000. Methods for measuring ileal amino acid digestibility in pigs. In: J.P.F. D’Mello (Editor). Farm Animal Metabolism and Nutrition. C.A.B. International, Wallingford (UK), pp. 279-306

Sauer W.C., Jørgensen H., Berzins R., 1983. A modified nylon bag technique for determining apparent digestibilities of protein in feedstuffs for pigs. Can. J. Anim. Sci. 63, 233-237

Sauer W.C., He J.M., Fan M.Z., Cervantes M., Kies A., Caine W., 2001. Variability of amino acid digestibility in pigs: inherent factors in feedstuffs and considerations in methodology. J. Anim. Feed Sci. 10, Suppl. 1, 115-138

Sauer W.C., Kennelly J.J., Aherne F.X., Cichon R.M., 1981. Availabilities of amino acids in barley and wheat for growing pigs. Can. J. Anim. Sci. 61, 793-802

Sauer W.C., Ozimek L., 1986. Digestibility of amino acids in swine: results and their practical applications. A review. Livest. Prod. Sci. 15, 367-388

Wang L., Newman R.K., Newman C.W., Hofer P.J., 1992. Barley $\beta$-glucans alter intestinal viscosity and reduce plasma cholesterol concentrations in chicks. J. Nutr. 122, 2292-2297

Wünsche J., Hermann U., Meinl M., Hennig U., Kreienbring F., Zwierz P., 1987. Einflu $\beta$ exogener Faktoren auf die präzäkale Nährstoff- und Aminosäuren Resorption, ermittelt an Schweinen mit Ileo-Rektal-Anastomosen. Arch. Anim. Nutr. (Berlin) 37, 745-764

\section{STRESZCZENIE}

Wartość pokarmowa jęczmienia zwyczajnego i bezłuskowego dla rosnących świń. 2. Oznaczenie strawności energii metodami in vivo i in vitro oraz jelitowej strawności aminokwasów metodą in vivo

Siedem wieprzków, o średniej m.c. $35 \mathrm{~kg}$ na początku i $90 \mathrm{~kg}$ na końcu doświadczenia, z prostymi T-przetokami do końcowego odcinka jelita biodrowego, żywiono siedmioma dietami (180 g białka ogólnego $\mathrm{kg}^{-1}$ ) w układzie kwadratu łacińskiego $7 \times 7$. Dawka podstawowa składała się ze skrobi kukurydzianej i poekstrakcyjnej śruty sojowej (SBM), pozostałe diety (A do F) - z SBM i jęczmienia: Dieta A: jęczmień zwyczajny, odm. Harrington I, dieta B: jęczmień zwyczajny Harrington II, dieta C - jęczmień bezłuskowy, odm. CDC Buck I, dieta D - jęczmień bezłuskowy, odm. Buck II, dieta E - mieszanka jęczmienia odm. Harrington I i CDC Buck I (50:50 wt/wt), dieta F - mieszanka jęczmienia odm. Harrington II i CDC Buck II (50:50 wt/wt). Odmiany I i II jęczmienia Harrington i Buck różniły się pochodzeniem. Skład diet ułożono w ten sposób, aby można było określić regresję liniową pomiędzy strawnością energii oznaczoną metodami in vivo i in vitro. Jako wskaźnik zastosowano $\mathrm{Cr}_{2} \mathrm{O}_{3}$. Paszę podawano dwa razy dziennie, o godz. 8.00 i 20.00. Każdy okres doświadczalny trwał 10 dni: kał zbierano od godz. 8.00 6-go dnia do godz. 8.00 - ósmego dnia okresu, a treść jelitową od 8.00 - ósmego dnia do godz. 8.00 10-go dnia.

Strawność aminokwasów (AA) i energii oznaczano metodą różnicową. Pozorna strawność AA jęczmienia bezłuskowego była niższa $(\mathrm{P}<0,05)$ niż zwyczajnego. Strawność lizyny i treoniny (pierwszego i drugiego aminokwasu ograniczającego w jęczmieniu) wahała się od 58,2 do 59,4\% i od 53,7 do 55,6\%, odpowiednio w jęczmieniu bezłuskowym, oraz od 62,6 do $69,7 \%$ i od 57,4 do $59,6 \%$, odpowiednio w jęczmieniu zwyczajnym. Strawność energii wahała się odpowiednio od 86,4 do $87,6 \%$ i od 79,9 do $81,1 \%$. Stwierdzono ścisłą korelację $\left(r^{2}=0,88\right)$ pomiędzy strawnością energii oznaczoną metodą in vivo i in vitro. 